\title{
Functional Live Cell Imaging of the Pulmonary Neuroepithelial Body Microenvironment
}

\author{
Ian De Proost ${ }^{1,3}$, Isabel Pintelon ${ }^{1}$, Inge Brouns ${ }^{1}$, Alfons B. A. Kroese ${ }^{2}$, Daniela Riccardi ${ }^{3}$, Paul J. Kemp ${ }^{3}$, \\ Jean-Pierre Timmermans ${ }^{1}$, and Dirk Adriaensen ${ }^{1}$ \\ ${ }^{1}$ Laboratory of Cell Biology and Histology, Department of Veterinary Sciences, University of Antwerp, Antwerp, Belgium; ${ }^{2}$ Institute for Risk \\ Assessment Sciences, University of Utrecht and Department of Surgery, UMC Utrecht, The Netherlands; and ${ }^{3}$ Cardiff School of Biosciences, \\ Cardiff University, Cardiff, United Kingdom
}

\begin{abstract}
Pulmonary neuroepithelial bodies (NEBs) are densely innervated groups of neuroendocrine cells invariably accompanied by Clara-like cells. Together with NEBs, Clara-like cells form the so-called "NEB microenvironment," which recently has been assigned a potential pulmonary stem cell niche. Conclusive data on the nature of physiological stimuli for NEBs are lacking. This study aimed at developing an ex vivo mouse lung vibratome slice model for confocal live cell imaging of physiological reactions in identified NEBs and surrounding epithelial cells. Immunohistochemistry of fixed slices demonstrated that NEBs are almost completely shielded from the airway lumen by tight junction-linked Clara-like cells. Besides the unambiguous identification of NEBs, the fluorescent dye 4-Di-2-ASP allowed microscopic identification of ciliated cells, Clara cells, and Clara-like cells in live lung slices. Using the mitochondrial uncoupler FCCP and a mitochondrial membrane potential indicator, JC-1, increases in 4-Di-2-ASP fluorescence in NEB cells and ciliated cells were shown to represent alterations in mitochondrial membrane potential. Changes in the intracellular free calcium concentration $\left(\left[\mathrm{Ca}^{2+}\right]_{\mathrm{i}}\right)$ in NEBs and surrounding airway epithelial cells were simultaneously monitored using the calcium indicator Fluo-4. Application $(5 \mathrm{~s})$ of $50 \mathrm{mM}$ extracellular potassium $\left(\left[\mathrm{K}^{+}\right]_{0}\right)$ evoked a fast and reproducible $\left[\mathrm{Ca}^{2+}\right]_{i}$ increase in NEB cells, while Clara-like cells displayed a delayed $( \pm 4 \mathrm{~s})\left[\mathrm{Ca}^{2+}\right]_{\mathrm{i}}$ increase, suggestive of an indirect, NEB-mediated activation. The presented approach opens interesting new perspectives for unraveling the functional significance of pulmonary NEBs in control lungs and disease models, and for the first time allows direct visualization of local interactions within the NEB microenvironment.
\end{abstract}

Keywords: mouse; lung; vibratome slices; NEBs; calcium imaging

Pulmonary neuroepithelial bodies (NEBs) (1) are organoid clusters of neuroendocrine cells located in the epithelium of the intrapulmonary airways of all air-breathing vertebrates (reviews in Refs. 2-4). NEBs are characterized by dense-cored secretory granules that contain bioactive substances, such as monoamine, peptide, and purine transmitters (reviews in Refs. 3-5) and are contacted by multiple nerve fiber populations (reviews in Refs. 2, 6, 7). The neuroendocrine cells of NEBs are

(Received in original form January 8, 2008 and in final form January 31, 2008)

This work was supported by the following research grants: Fund for Scientific Research-Flanders (G.0085.04 and G.0081.08 to D.A.); NOI BOF UA 2003 and GOA BOF UA 2007 (to D.A.) and KP BOF UA 2006 (to I.B.) from the University of Antwerp; Biotechnology and Biological Sciences Research Council (BBSRC, BB/ D01591X/1 to P.J.K. and D.R.).

Correspondence and requests for reprints should be addressed to Dirk Adriaensen, Ph.D., Laboratory of Cell Biology and Histology, Department of Veterinary Sciences, University of Antwerp, Groenenborgerlaan 171, B-2020 Antwerp, Belgium. E-mail: dirk.adriaensen@ua.ac.be

This article has an online supplement, which is accessible from this issue's table of contents at www.atsjournals.org

Am J Respir Cell Mol Biol Vol 39. pp 180-189, 2008

Originally Published in Press as DOI: 10.1165/rcmb.2008-00110C on March 26, 2008

Internet address: www.atsjournals.org

\section{CLINICAL RELEVANCE}

A unique functional live cell imaging model is developed for studying the airway neuroepithelial body "microenvironment," which is believed to represent an important lung stem cell niche involved in airway epithelial regeneration and lung carcinogenesis.

located between a variety of other epithelial cells such as Clara cells, ciliated cells, and small polyhedric basal cells. Electron microscopic studies have revealed that a specific type of nonciliated epithelial cells, the so-called Clara-like cells (8), is closely associated with NEBs $(9,10)$. Although there may be species- and age-dependent differences in their appearance, electron microscopy revealed that Clara-like cells cover at least large parts of the apical and lateral surfaces of NEBs, with apical process of NEB cells reaching the airway lumen (8). It has been shown that this specialized type of Clara-like cell is clearly distinct from the other Clara cells in the airway epithelium. Clara-like cells appear to have features of pluripotent stem cells, are believed to be involved in airway epithelium regeneration (11-14), and together with NEBs form the socalled "NEB microenvironment."

Even though many, mainly morphologic, data are supportive of a role for NEBs as complex intraepithelial sensory airway receptors, conclusive physiological data on their exact function in the healthy lungs are lacking. Direct in vivo physiological studies of pulmonary NEBs are currently impossible because of their inaccessibility, their relatively small number, and their widespread distribution throughout the airway epithelium, prompting the development of reliable in vitro models. Studies in organ cultures (15), cultures of isolated pulmonary neuroendocrine cells (PNECs) (16-18), and neuroendocrine cell lines $(19,20)$ have provided some of the limited data concerning the physiology of pulmonary NEBs available today. Nevertheless, morphologic research has suggested that NEB function might be modulated by their extensive innervation and the local environment $(2,6,21)$. Such cell-cell interactions cannot be studied in the current in vitro models. Consequently, there has been development of ex vivo models using precision-cut vibratome lung slices (22), to study NEB function in a relatively native environment.

Lung slices, in which NEBs were visualized using neutral red staining, have been used for the functional study of NEBs by whole cell patch-clamp recordings (22) and amperometry (23). Recently, we have developed a method, using the styryl pyridinium dye 4-(4-diethylaminostryryl)- $N$-methylpyridinium iodide (4-Di-2-ASP), which allows for the fluorescent labeling of pulmonary NEBs in the airway epithelium of live lung slices (24). The main goal of the present study was to further establish this ex vivo lung slice model for live cell imaging, to visualize 
the physiological activation of NEBs in their "natural" environment by an applied stimulus. Because 4-Di-2-ASP is believed to be taken up in mitochondria of living cells (25), and several styryl dyes have been reported to be fluorescent indicators of changes in mitochondrial membrane potential $\left(\Delta \psi_{\mathrm{m}}\right)(25-27)$, we investigated the ability of 4-Di-2-ASP to reflect changes in the $\Delta \psi_{\mathrm{m}}$ of NEB cells. Furthermore, we developed a method that could simultaneously label NEBs and reflect changes in intracellular calcium concentration, in an attempt to unravel the potential function(s) of NEBs.

\section{MATERIALS AND METHODS}

\section{Animals}

Lung tissue was obtained from 5- to 20-d-old C57-B16 mice $(n=35$, Janvier; Bio Services, Uden, The Netherlands). All animals were housed with their mothers in acrylic cages in an acclimatized room $\left(12 / 12 \mathrm{~h}\right.$ light/dark cycle; $\left.22 \pm 3^{\circ} \mathrm{C}\right)$ and were provided with water and food ad libitum. National and international principles of laboratory animal care were followed and experiments were approved by the local animal ethics committee of the University of Antwerp.

\section{Drugs, Solutions, and Perfusion}

A standard physiological solution was used throughout, which contained (in $\mathrm{mM}$ ) NaCl, $130 ; \mathrm{KCl}, 5 ; \mathrm{CaCl}_{2}, 1.2 ; \mathrm{MgSO}_{4}, 1 ; \mathrm{D}$-glucose, 11 ; HEPES, 20; pH 7.42 adjusted with $\mathrm{NaOH}$. Solutions containing a high extracellular potassium concentration $\left(\left[\mathrm{K}^{+}\right]_{\mathrm{o}}\right)$ were prepared by equimolar substitution of $\mathrm{KCl}$ for $\mathrm{NaCl}$. For $\mathrm{Ca}^{2+}$-free solution, $\mathrm{CaCl}_{2}$ was replaced by $1 \mathrm{mM}$ ethylenediamine tetra-acetic acid disodium salt dihydrate (EDTA).

All chemicals were purchased from Sigma-Aldrich (Bornem, Belgium), except for Fluo-4 AM (F14201), JC-1 (5,5',6,6' -tetrachloro$1,1^{\prime}, 3,3^{\prime}$ tetraethyl benzimidazolyl carbocyanine iodide/chloride, T3168), and 4-Di-2-ASP (D-289), which were purchased from Molecular Probes (Invitrogen, Merelbeke, Belgium).

All stimuli were applied to lung slices that were submerged in a tissue bath $(2 \mathrm{ml})$ mounted on the microscope stage, perfused by a gravity-fed system (flow rate of $>5 \mathrm{ml} / \mathrm{min}$ ) with electrically triggered valves that allowed the fast exchange of experimental solutions.

\section{Preparation of Live Lung Slices and Specific Staining of NEBs}

Lung slices were prepared and stained as previously published (24). In short, lung tissue was stabilized by instillation of a $2 \%$ agarose solution (low-melt agarose, A4018; Sigma). Lung slices were cut using a vibratome (HM650 V; Microm International, Walldorf, Germany) and subsequently incubated for 4 minutes with $4 \mu \mathrm{M}$ 4-Di-2-ASP in Dulbecco's modified Eagle's medium/F-12 (DMEM-F-12; Gibco, Invitrogen) at $37^{\circ} \mathrm{C}$, rinsed, and kept in DMEM-F-12 in an incubator $\left(37^{\circ} \mathrm{C} ; 5 \% \mathrm{CO}_{2} /\right.$ $95 \%$ air) until required. All lung slices were used within 12 hours of killing the animal, as there was no visible decline in cell viability during this period (24).

\section{$\Delta \psi_{\mathrm{m}}$ Indicator Loading Procedure}

JC-1 is a lipophilic membrane-permeant cation that selectively enters mitochondria and exists in a monomeric form (green fluorescence), or an aggregated form (red fluorescence) upon mitochondrial hyperpolarization. Therefore, a decrease in JC-1 red/green fluorescence ratio indicates mitochondrial depolarization. In the present study, lung slices were incubated with $11 \mu \mathrm{M} \mathrm{JC}-1$ and $0.1 \%$ dimethyl sulfoxide (DMSO) in DMEM-F-12 at $37^{\circ} \mathrm{C}(1 \mathrm{~h})$. The slices were subsequently washed $(10 \mathrm{~min})$ in physiological solution to allow for complete deesterification of intracellular JC-1.

\section{$\mathrm{Ca}^{2+}$ Indicator Loading Procedure}

Lung slices were incubated in physiological solution with the $\mathrm{Ca}^{2+}$ indicator Fluo-4 AM $(10 \mu \mathrm{M}), 100 \mu \mathrm{M}$ sulfobromophtalein, $0.1 \%$ DMSO, and $0.02 \%$ Pluronic F-127 for 1 hour at room temperature (RT). The slices were subsequently washed $(10 \mathrm{~min}, \mathrm{RT})$ in physiological solution to allow for complete deesterification of intracellular Fluo-4 AM.

\section{Viability Test with Propidium lodide}

As previously described (24), the viability of 4-Di-2-ASP-stained and Fluo-4-loaded lung slices was checked using propidium iodide (PI). In short, lung slices were incubated for 1 minute in $5 \mu \mathrm{M}$ PI in physiological solution and subsequently rinsed for 15 minutes in physiological solution.

\section{Immunohistochemical Labeling of Fixed Lung Slices}

Immunohistochemical incubations were performed at RT on freefloating lung slices in closed Eppendorf tubes. For the visualization of Urine Protein 1 (UP1), a protein that has a high amino acid sequence homology with the $10-\mathrm{kD}$ Clara cell secretory protein (28) and consequently labels all Clara cells, freshly cut lung slices were fixed $(1 \mathrm{~h})$ with $4 \%$ paraformaldehyde (in $0.1 \mathrm{M}$ phosphate buffer; $\mathrm{pH} 7.4$ ). The primary and secondary antisera were diluted in phospate-buffered saline (PBS; $0.01 \mathrm{M}, \mathrm{pH} 7.4$ ) containing $10 \%$ normal goat serum, $0.1 \%$ bovine serum albumin, $0.05 \%$ thimerosal, and $0.01 \% \mathrm{NaN}_{3}$ (PBS*). Before incubation with the primary antisera, lung slices were incubated for 1 hour with PBS* containing 1\% Triton-X-100. Slices were incubated overnight with a polyclonal primary antibody raised in rabbit (Rb Pc) against UP1 (1:200; Dakocytomation A0257, Glostrup, Denmark). To visualize immunoreactivity for UP1, lung slices were further incubated for 4 hours with Cy3-conjugated Fab fragments of goat antirabbit immunoglobulins (GAR-Fab-Cy3, 1:2,000, 111-167-003; Jackson ImmunoResearch, West Grove, PA). As previously described $(29,30)$, the use of GAR-Fab fragments allows for combination with a second primary antiserum raised in rabbits. Sections were then incubated for a consecutive night with a second primary antibody against proteingene product 9.5 (PGP9.5, 1:4,000, 7863-0507, Rb Pc; Biogenesis, Poole, UK), a pan-neuronal and neuroendocrine marker, followed by a 4-hour secondary incubation with fluorescein isothiocyanate (FITC)-conjugated Fab fragments of goat anti-rabbit immunoglobulins (GAR-Fab-FITC, 1:100, 111-097-003; Jackson ImmunoResearch).

For visualization of the tight junction protein occludin, slices were fixed in ice-cold acetone for 10 minutes and rehydrated with PBS. Preincubation $(1 \mathrm{~h})$ with PBS* containing $1 \%$ Triton-X-100 was followed by incubation with the primary antiserum against occludin (1:50; Rb Pc, overnight; 71-1500; Zymed Laboratories; San Francisco, CA). The primary antibody was visualized by Cy3-conjugated goat anti-rabbit immunoglobulins (GAR-Cy3, 1 h, 1:200, 111-165-144; Jackson ImmunoResearch). Lung slices were subsequently double labeled for PGP9.5 as outlined above. After a final wash in PBS, the lung slices were mounted in Citifluor (Ted Pella 19470, Redding, CA).

\section{Control Experiments for the Immunohistochemical Procedures}

Negative staining controls for all immunohistochemical procedures were performed by substitution of nonimmune sera for the primary or secondary antisera. The general specificity of the primary antibodies for their respective antigens was proven by the selective staining of the expected tissue elements. Since immunocytochemical staining was performed to obtain structural information only, further specificity controls were not considered to be relevant.

\section{Microscopic Data Aquisition}

An inverted microscope (Zeiss Axiovert 200; Carl Zeiss, Jena, Germany), attached to a microlens-enhanced dual spinning disk confocal system (UltraVIEW ERS; PerkinElmer, Seer Green, UK), equipped with a three-line $(488,568$, and $647 \mathrm{~nm})$ argon-krypton laser, for excitation of the FITC, $\mathrm{Cy} 3$, and $\mathrm{Cy} 5$ labels, respectively, was used for all high-resolution imaging in the lung slices.

All live cell imaging experiments were performed at RT. Lung slices were transferred to the perfusion chamber on the microscope stage and kept in place with a small sheet of nylon mesh attached to a golden ring. Pulmonary NEBs were studied at all levels of the intrapulmonary airways. Time-lapse experiments were mainly recorded in a single confocal plane with a plan apo $\times 40 / 1.30$ N.A. objective lens (Carl Zeiss), and a standard subarray of $336 \times 256$ pixels (center quarter) was selected for imaging. To avoid phototoxicity and photobleaching, laser illumination was kept to a minimum. Changes in 4-Di-2-ASP fluorescence (excitation max. $488 \mathrm{~nm}$; emission max. $607 \mathrm{~nm}$ ) were 
recorded ( 2 images/s) using the 568-nm line for excitation while the emitted fluorescence was selected by a Cy3 emission filter (dichroic mirror 488/568/647; bandpass 575-660). Time-lapse images of changes in Fluo-4 fluorescence (excitation max. $494 \mathrm{~nm}$; emission max. $516 \mathrm{~nm}$ ) were recorded ( 2 images/s) by 488 -nm laser excitation and a FITC emission filter (dichroic mirror 488/568/647; bandpass 500-560) detection. For the measurement of changes in JC-1 red/green fluorescence ratio, we sequentially excited at $488 \mathrm{~nm}$ and $568 \mathrm{~nm}$ and captured the emitted fluorescence as described for recording Fluo-4 and 4-Di-2ASP fluorescence. Ciliary movement was recorded in combination with 4-Di-2-ASP or Fluo-4 fluorescence, by sequentially capturing a transmitted light and a fluorescence image with the above-described settings. For the simultaneous measurement of changes in Fluo-4 and 4-Di-2-ASP fluorescence, both indicators were sequentially excited, resulting in a time resolution of one double exposure image/s.

\section{Data Analysis}

Time-lapse recordings were analyzed off-line by Volocity 2 software (Improvision, Coventry, UK). For analysis, images were studied as gray level value datasets. Regions of interest (ROI) were manually drawn around identified cells of interest. For every ROI, the fluorescence intensity expressed as arbitrary units was plotted against time. To facilitate interpretation of the results, gray levels were adjusted for the basal level of fluorescence that was present at the start of imaging. All fluorescence values presented are relative; therefore, changes in 4-Di-2ASP and Fluo-4 fluorescence can only be interpreted as relative changes in $\Delta \psi_{\mathrm{m}}$ or $\left[\mathrm{Ca}^{2+}\right]_{\mathrm{i}}$, respectively. All graphs presented are representative of multiple experiments performed under the respective conditions.

\section{RESULTS}

\section{4-Di-2-ASP Staining Pattern of the Airway Epithelium in Murine Lung Slices}

Observation of lung slices after incubation with 4-Di-2-ASP, viewed from the luminal side of sectioned airways, displayed a mosaic of polygonal fluorescent epithelial cells, intermingled with almost nonfluorescent rounded cells (Figure 1A). Sequential time-lapse imaging of 4-Di-2-ASP fluorescence and transmitted light images identified the 4-Di-2-ASP fluorescent cells as ciliated epithelial cells that showed beating cilia (see Video E1 in the online supplement). The nonfluorescent, nonciliated cells (Video E1) were reminiscent of Clara cells. Scattered throughout the airway epithelium, conspicuous 4-Di-2-ASP fluorescent clusters of small, rounded epithelial cells could be identified as pulmonary NEBs (Figures 1A and 1B). NEB cells were found to be typically surrounded by a continuous layer of nonfluorescent Clara cells, the so-called Clara-like cells (Figure 1B).

\section{Depolarization of Mitochondria in 4-Di-2-ASP-Labeled Airway Epithelial Cells by FCCP}

Application to 4-Di-2-ASP stained lung slices of carbonyl cyanide 4-(trifluoromethoxy)phenylhydrazone (FCCP; $10 \mu \mathrm{M}$; $10 \mathrm{~s}), \mathrm{a} \mathrm{H}^{+}$ionophore that uncouples oxidative phosphorylation and depolarizes mitochondria, evoked a simultaneous increase in 4-Di-2-ASP fluorescence in all NEB cells and in ciliated epithelial cells (Figures 1C-1E; Video E2). The responses started $3.6 \pm 1.2$ seconds $(n=11)$ after addition of FCCP to the recording chamber. Upon returning to normal physiological solution, 4-Di-2-ASP fluorescence in both cell types dropped to baseline levels within 3 minutes. Repetitive stimulation with FCCP caused consecutive increases in 4-Di-2-ASP fluorescence. No alterations in 4-Di-2-ASP fluorescence were observed in the virtually nonstained Clara and Clara-like cells (Figures 1C-1E).

\section{Fluo-4 Fluorescence in the Airway Epithelium in Murine Lung Slices}

Microscopic investigation of Fluo-4-loaded epithelium from the luminal side of sectioned airways revealed a population of polygonal epithelial cells that emitted a much brighter fluorescence than the remainder of the epithelial cells (Figure 2A). Sequential time-lapse imaging of Fluo-4 fluorescence and transmitted light images revealed that the Fluo-4 fluorescent cell population corresponded to cells with actively beating cilia (Figures 2B-2E; Video E3). Subsequently, the nonciliated, nonfluorescent cells were identified as Clara cells. Staining with PI did not reveal nuclear staining in airway epithelial cells. PIstained nuclei were, however, occasionally observed in smooth muscle cells underneath the epithelium (Figure 2C).

Stimulation of Fluo-4-loaded lung slices with $10 \mu \mathrm{M}$ ATP (5 s) caused a clearly visible and reproducible rise in Fluo-4 fluorescence in all Clara cells and, to a lesser extent, also in ciliated cells (Figures 2F-2H; Video E4).

\section{Fluorescence Pattern in 4-Di-2-ASP-Stained, Fluo-4-Loaded Airway Epithelium in Murine Lung Slices}

Confocal imaging of 4-Di-2-ASP-stained and Fluo-4-loaded lung slices enabled the easy and reproducible identification of individual NEB cells and Clara-like cells. A basal low Fluo-4 fluorescence intensity, comparable with that observed in Clara cells, was typical for both cell types. As expected, the high basal fluorescence of 4-Di-2-ASP and Fluo-4 co-localized in ciliated cells (Figures 3A-3C).

\section{Elevation of $\left[\mathrm{K}^{+}\right]_{o}$ Mediates a $\left[\mathrm{Ca}^{2+}\right]_{i}$ Rise in Selective Groups of Airway Epithelial Cells}

Figures $4 \mathrm{~A}-4 \mathrm{~F}$ and Video E5 show typical recordings of the changes in Fluo-4 fluorescence observed after short-term elevation of $\left[\mathrm{K}^{+}\right]_{\mathrm{o}}$, as visualized in a NEB and in the surrounding airway epithelial cells. Increasing $\left[\mathrm{K}^{+}\right]_{\mathrm{o}}$ in the perfusion bath from 5 to $20 \mathrm{mM}$ for 5 seconds caused a simultaneous increase in Fluo-4 fluorescence in all NEB cells, identified by their 4-Di2 -ASP staining. Responses started $1.5 \pm 0.6 \mathrm{~s}(n=15)$ after high $\left[\mathrm{K}^{+}\right]_{\mathrm{o}}$ entered the bath. After removal of the stimulus, Fluo-4 fluorescence in NEB cells decreased toward basal levels within 3 minutes. The amplitude of the Fluo-4 fluorescence increase induced in the NEB cells by a pulse of high $\left[\mathrm{K}^{+}\right]_{\mathrm{o}}$ was concentration-dependent. Consecutive exposure of lung slices for 5 seconds to $20,40,60,80$, and $100 \mathrm{mM}\left[\mathrm{K}^{+}\right]_{\mathrm{o}}$ evoked single peak responses displaying a progressively larger amplitude (Figure 4G). Based on the dose-response curve for high $\left[\mathrm{K}^{+}\right]_{\mathrm{o}}$ and the $\mathrm{EC}_{50}(52.9 \mathrm{mM})$, a working concentration of $50 \mathrm{mM}$ $\left[\mathrm{K}^{+}\right]_{\mathrm{o}}$ was chosen for further experiments. Repetitive exposure to $50 \mathrm{mM}\left[\mathrm{K}^{+}\right]_{\mathrm{o}}(5 \mathrm{~s})$ at 5-minute intervals resulted in consecutive increases of Fluo-4 fluorescence.

Importantly, the observed changes in NEB cells were always followed by an increase in Fluo-4 fluorescence in Clara-like cells surrounding the NEBs, but with a 4.2- \pm 1 .9-second $(n=80)$ delay compared with the rise seen in NEB cells (Figure 4A; Video E5). No other epithelial cells showed a rise in $\left[\mathrm{Ca}^{2+}\right]_{i}$ in response to elevation of $\left[\mathrm{K}^{+}\right]_{\mathrm{o}}$

\section{Simultaneous Measurement of Changes in $\Delta \psi_{m}$ and $\left[\mathrm{Ca}^{2+}\right]_{i}$ in} Airway Epithelial Cells after Stimulation with High $\left[\mathrm{K}^{+}\right]_{\mathrm{o}}$

Sequential time-lapse imaging of Fluo-4 and 4-Di-2-ASP fluorescence in NEB cells (Figures 5A and 5B; Video E6) revealed that stimulation with high $\left[\mathrm{K}^{+}\right]_{\mathrm{o}}$ not only evoked a cytoplasmic rise in Fluo-4 fluorescence, but also a visible increase in 4-Di-2-ASP fluorescence, indicative of $\Delta \psi_{\mathrm{m}}$ depolarization. The latter response started $5.5 \pm 0.9 \operatorname{seconds}(n=17)$ after high $\left[\mathrm{K}^{+}\right]_{\mathrm{o}}$ entering the bath. No such change was observed in any other epithelial cell.

Responses to high $\left[\mathrm{K}^{+}\right]_{\mathrm{o}}$ of Fluo-4 and 4-Di-2-ASP in NEB cells, and of Fluo-4 in Clara-like cells, were fully abolished in a $\mathrm{Ca}^{2+}$-free environment. Upon returning to normal physiological solution, all NEB cells $(n=13)$ and $54 \%$ of the Clara-like 

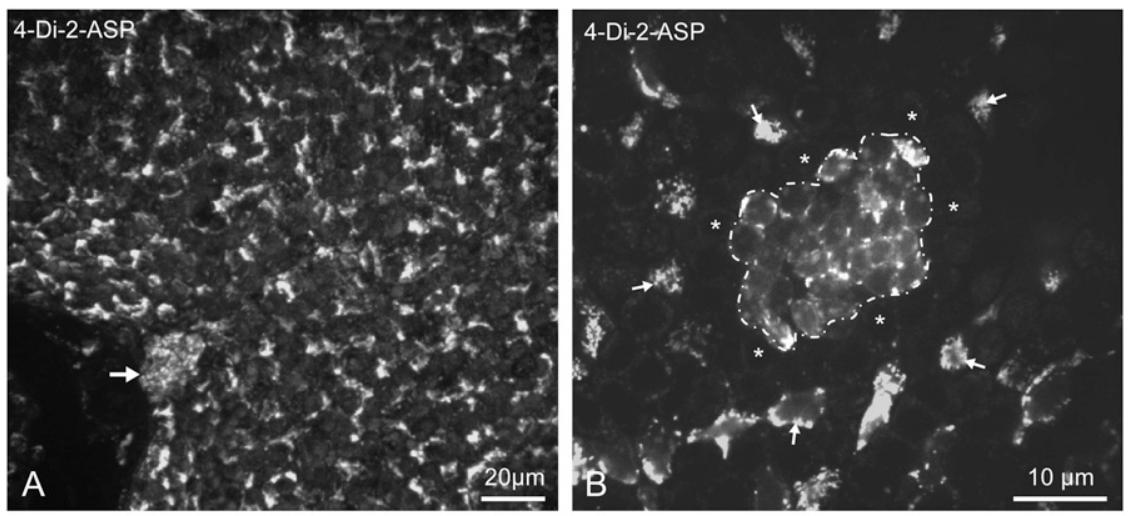

Figure 1. (A) Incubation of an ex vivo mouse lung slice with 4-(4-diethylaminostryryl)- $N$-methylpyridinium iodide (4-Di-2-ASP) reveals an extensive population of fluorescent airway epithelial cells when viewed from the airway lumen. In addition, a compact group of smaller 4-Di-2-ASP fluorescent cells known to represent a pulmonary neuroepithelial body (NEB) can be recognized (arrow). (B) Detail of a NEB (encircled) labeled with 4-Di-2-ASP, illustrating that the NEB cells are always surrounded by a rim of nonfluorescent Clara cells (asterisks), the so-called Clara-like cells, and are never contacted by 4-Di-2-ASP fluorescent ciliated cells (arrows). (C$E$ ) Representative recordings of changes in 4-Di-2ASP fluorescence measured in NEB cells, Clara-like cells, Clara cells, and ciliated cells in a murine lung slice before, during, and after stimulation with the mitochondrial uncoupler FCCP $(10 \mu \mathrm{M}, 10 \mathrm{~s})$. (C) Graph plotting the time course of 4-Di-2-ASP fluorescence intensity as observed during administration of FCCP. The regions of interest (ROI) correspond to the NEB (ROI 1), Clara-like cells (ROI 2), Clara cells (ROI 3), and ciliated cells (ROI 4) depicted in $D$. $(D, E)$ Images of 4-Di-2-ASP fluorescence in a NEB and surrounding airway epithelial cells at two different time points, indicated in the graph as $\mathrm{T} 1$ and $\mathrm{T} 2$, respectively, which correspond to frames taken before and after stimulation with FCCP. The 4-Di-2-ASP fluorescent NEB and ciliated cells appear to respond to depolarization of $\Delta \psi_{\mathrm{m}}$ with a cytoplasmic rise in 4-Di2-ASP fluorescence. Note that the staining pattern changes from small punctuate fluorescent dots $(D)$ to a more diffuse cytoplasmic fluorescence $(E)$. L, airway lumen. Time-lapse images are shown in Video E2 in the online supplement.
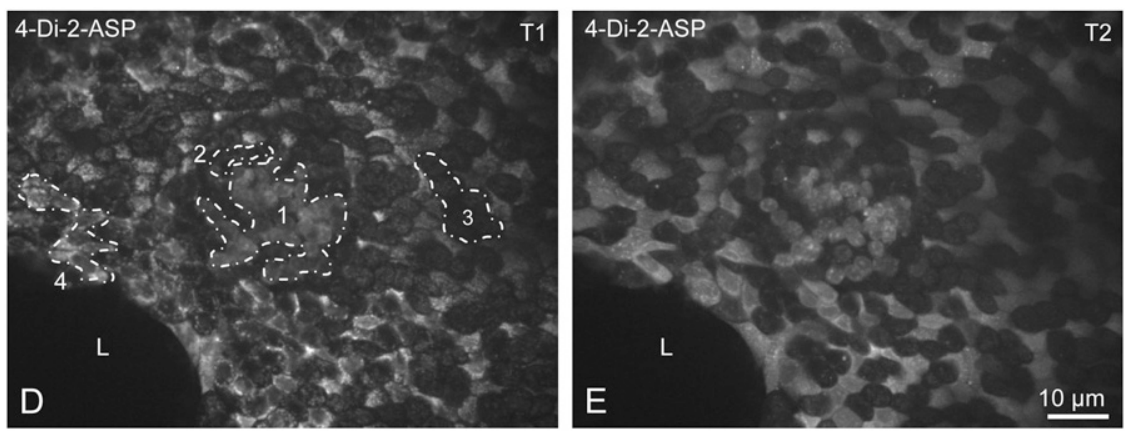

cells $(n=46)$ could be activated with high $\left[\mathrm{K}^{+}\right]_{\mathrm{o}}$ for a second time (Figures 5C and 5D). So far, it is not clear why, in contrast to all NEB cells, only about half of the Clara-like cells showed a rise in $\left[\mathrm{Ca}^{2+}\right]_{\mathrm{i}}$ in response to high $\left[\mathrm{K}^{+}\right]_{\mathrm{o}}$ upon returning from the $\mathrm{Ca}^{2+}$-free condition.

\section{Depolarization of Mitochondria in JC-1-Labeled Airway Epithelial Cells by FCCP and High $\left[\mathrm{K}^{+}\right]_{\mathrm{o}}$}

JC-1 was used as a control $\Delta \psi_{\mathrm{m}}$ indicator, because of its established ability to detect changes in $\Delta \psi_{\mathrm{m}}$ in living cells. Microscopic inspection of JC-1 loaded lung slices allowed identification of red fluorescent polygonal ciliated cells that intermingled with rounded nonfluorescent Clara cells (Figure 6A). We could identify clusters of red fluorescent NEB cells surrounded by a circle of nonfluorescent Clara-like cells (Figure 6A). As a positive control, stimulation of JC-1 loaded lung slices with the mitochondrial uncoupler FCCP $(10 \mu \mathrm{M} ; 20 \mathrm{~s})$ evoked a decrease in the red/green fluorescence intensity ratio, indicative for $\Delta \psi_{\mathrm{m}}$ depolarization, simultaneously in all epithelial cells (Figure $6 \mathrm{~B}$; Video E7). Upon washout, the fluorescence ratio did not return to baseline within 5 minutes. Stimulation $(30 \mathrm{~s})$ of JC-1loaded lung slices with $50 \mathrm{mM}\left[\mathrm{K}^{+}\right]_{\mathrm{o}}$ resulted in a decrease of the $\mathrm{red} /$ green fluorescence intensity ratio in NEB cells, but not in other airway epithelial cells (Figure 6C). The fluorescence ratio in NEB cells did not return to baseline upon washout.
Immunohistochemical Visualization in Lung Slices of NEBs, Clara Cells, and Tight Junctions in the Airway Epithelium

Double immunostainings for UP1, as a Clara cell marker, and PGP9.5 in fixed murine lung slices revealed that PGP9.5immunoreactive NEB cells are invariably surrounded and covered by UP1-immunoreactive Clara cells. Transversally sectioned NEBs displayed an almost complete shielding of NEB cells from the airway lumen by Clara-like cells. Apparently, NEB cells reach the airspace with only the tips of their thin apical processes (Figures 7A-7C). Furthermore, confocal tangential views of the airway epithelium immunostained for the tight junction protein occludin clearly illustrate that the apical borders of airway epithelial cells are sealed to each other by tight junctions, resulting in a polygonal pattern (Figures 7D-7F). When focusing on NEBs, the pattern appears to be disturbed, with groups of large surfaced cells separated by very small areas on top of NEB cells. The latter represent tight junction seals around the thin processes of NEB cells that reach the airway lumen.

\section{DISCUSSION}

The present paper introduces a novel ex vivo live cell imaging model for the physiological study of pulmonary NEBs and associated epithelial cells in murine lung slices. The model allows microscopic identification of NEBs, ciliated cells, Clara 

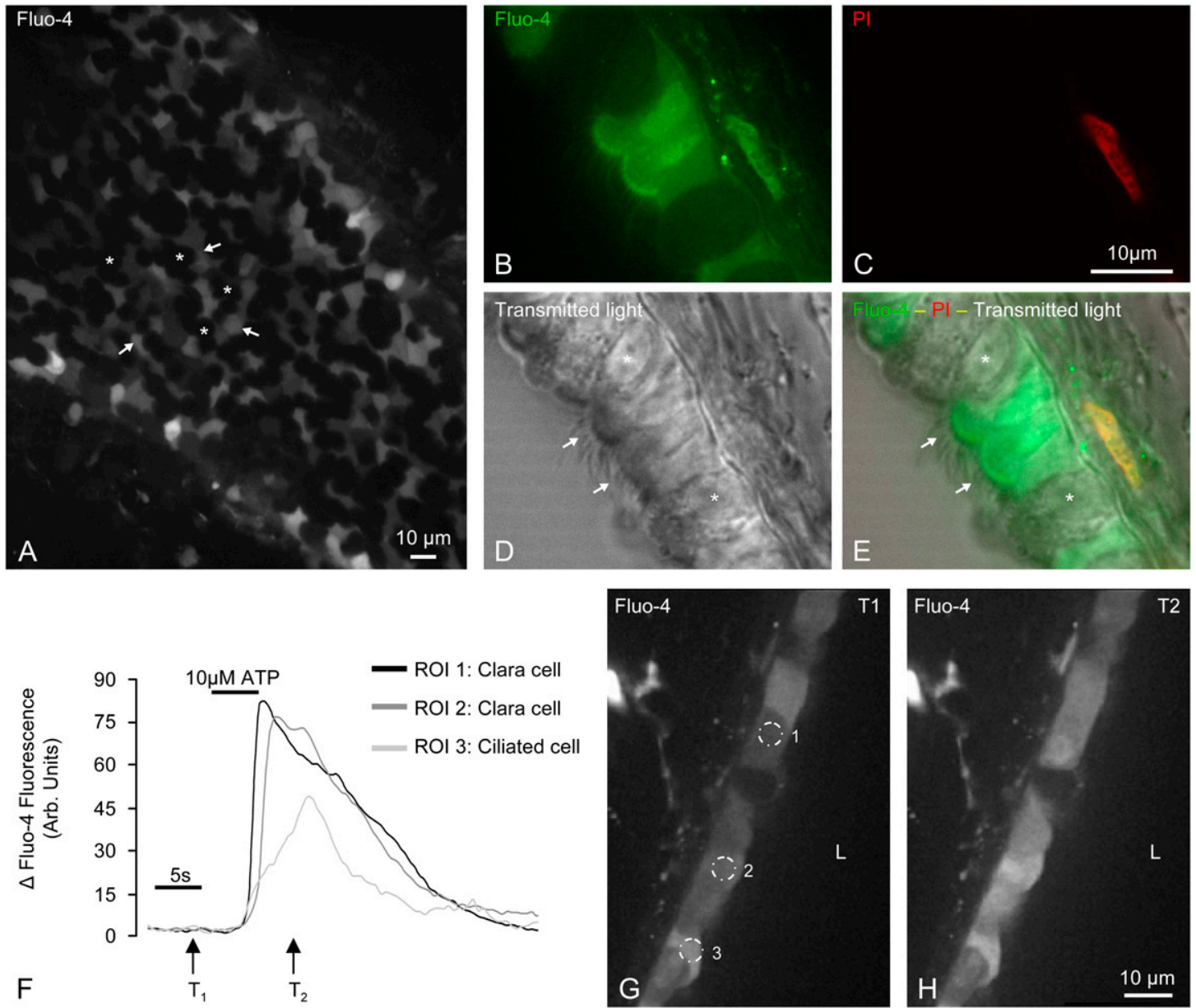

Figure 2. (A) Overview of a mouse airway loaded with Fluo-4 AM, showing polygonal epithelial cells with an intense basal Fluo-4 fluorescence (arrows), intermingled with rounded and virtually nonfluorescent cells (asterisks). (B$E)$ High magnification confocal imaging of transversally "sectioned" Fluo-4-loaded epithelial cells in an airway. (B) High basal Fluo-4 fluorescence (green) is observed in some epithelial cells, while other nearby cells are almost nonfluorescent. (C) Propidium iodide fluorescence (PI, red), as a marker of cells with permeable membranes, is observed in a smooth muscle cell nucleus. (D) Brightfield image showing ciliated (arrows) and nonciliated cells (asterisks). (E) Combination of the three channels confirms that the ciliated cells correspond to the cells that show an intense Fluo-4 fluorescence, while the

nonciliated cells are virtually nonfluorescent. Furthermore, PI staining reveals that all airway epithelial cell types remain intact after vibratome slicing and Fluo-4 loading procedures. Time-lapse images are shown in Video E3. (F-H) Representative recordings of changes in Fluo-4 fluorescence measured in murine airway epithelial cells in a Fluo-4-loaded lung slice before, during, and after stimulation with ATP $(10 \mu \mathrm{M}, 5 \mathrm{~s})$. ( $F$ ) Graph plotting the time course of changes in Fluo-4 fluorescence intensity. ROls 1 and 2 correspond to Clara cells, ROI 3 to a ciliated cell depicted in $G$. ( $G, H$ ) Images of Fluo-4 fluorescence in the airway epithelium at two different time points, indicated in the graph as T1 and T2, which correspond to the images taken just before and after application of ATP. The Clara cells and the ciliated cell respond to ATP stimulation with a cytoplasmic rise in Fluo-4 fluorescence, corresponding to an increase in $\left[\mathrm{Ca}^{2+}\right]_{i}$ that drops back to basal levels upon wash-out. $\mathrm{L}$, airway lumen. Time-lapse images are shown in Video $\mathrm{E} 4$.

cells, and Clara-like cells, and responses of NEB cells and other cells to applied stimuli can be visualized in real time using fluorescent probes and confocal microscopy. The opportunity to study simultaneously multiple NEB cells and their interactions with surrounding cells and tissues are important advantages of this new approach.
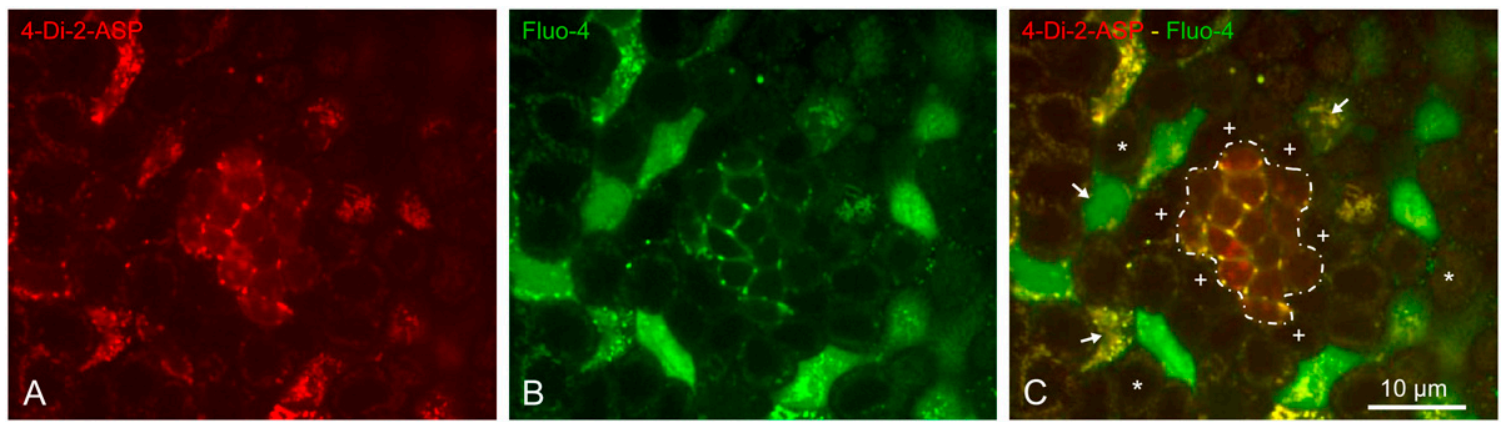

Figure 3. Maximum intensity projection of confocal images showing a luminal view of a mouse airway stained with 4-Di-2-ASP ( $A$; red fluorescence) and loaded with Fluo-4 ( $B$; green fluorescence). $(C)$ Combination of both channels. Labeling with 4-Di-2-ASP allows identification of the NEB (encircled), revealing that basal Fluo-4 fluorescence in NEB cells is limited, making it hard to discriminate them from the surrounding epithelial cells based on Fluo-4 loading alone. Note that ciliated cells (arrows) show bright 4-Di-2-ASP and Fluo-4 fluorescence, while Clara cells (asterisks) and Clara-like cells (crosses) surrounding NEBs are virtually nonfluorescent. 

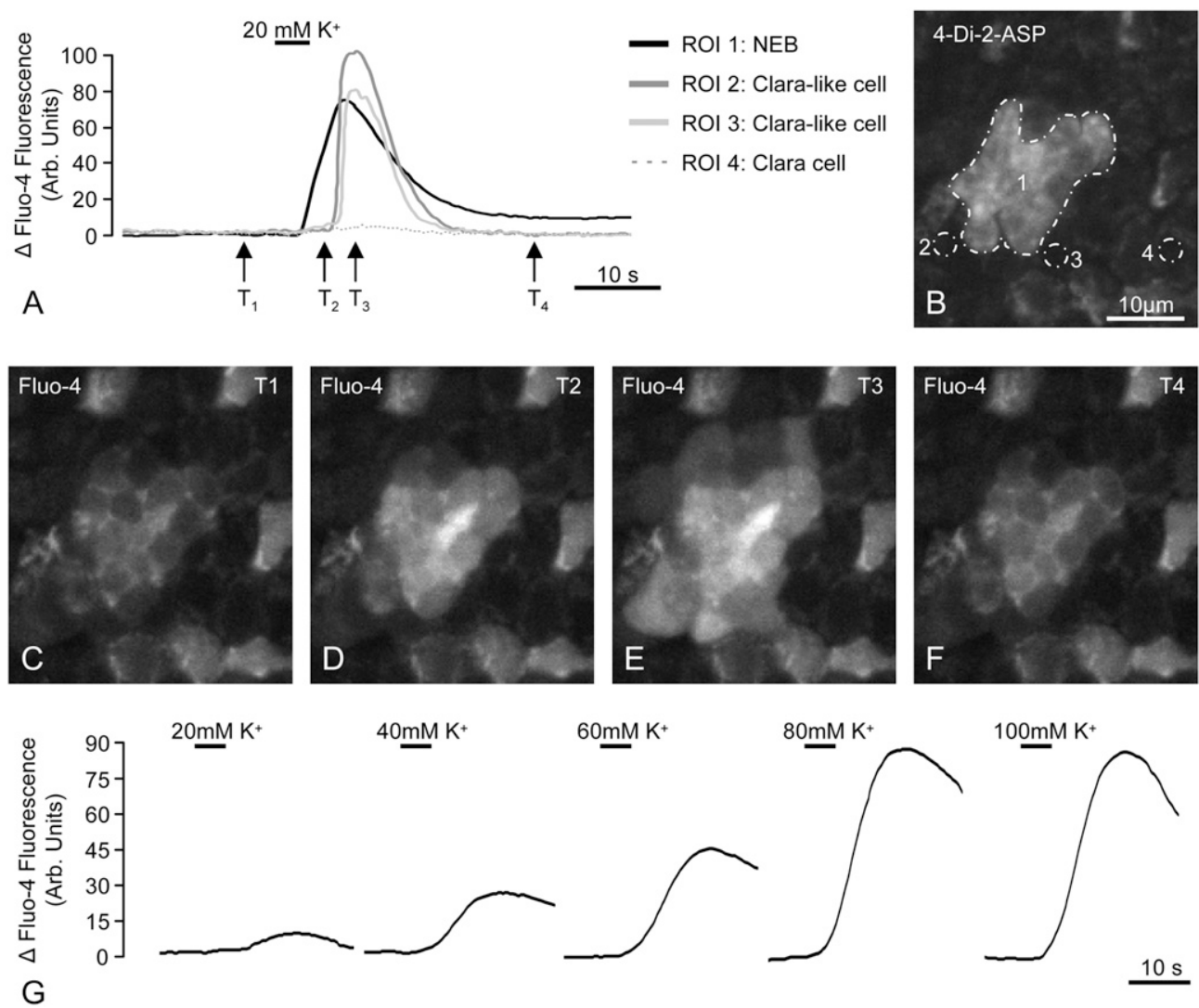

Figure 4. $(A-F)$ A representative recording of the Fluo-4 fluorescence changes measured in NEB cells and surrounding Clara-like cells in a 4-Di2-ASP-stained, Fluo-4-loaded murine lung slice, before, during, and after a 5 -second challenge with $20 \mathrm{mM}\left[\mathrm{K}^{+}\right]_{\mathrm{o}}$. (A) Graph plotting the time course of changes in Fluo-4 fluorescence intensity. ROI 1-4 in the graph correspond to the NEB (ROI 1), Clara-like cells (ROI 2-3), and Clara cell (ROI 4) depicted in $B$. (B) Image of 4-Di-2-ASP staining recorded before the experiment, showing an NEB that is easily differentiated from the nonfluorescent Clara-like cells. $(C-F)$ Time-lapse images of Fluo4 fluorescence in the NEB and surrounding epithelial cells at different time points, indicated in the graph as T1-T4. NEB cells respond to a pulse of high $\left[\mathrm{K}^{+}\right]_{0}$ with a clear rise in Fluo-4 fluorescence $(D)$, apparently a few seconds before Clara-like cells do $(E)$. Time-lapse images are shown in Video E5. (G) Graphs showing changes in Fluo-4 fluorescence as measured from NEBs $(n=15)$ in 4-Di-2-ASP-stained, Fluo-4-loaded ex vivo vibratome slices, evoked by 5 -second applications of increasing concentrations of $\left[\mathrm{K}^{+}\right]_{\mathrm{o}}(20$, $40,60,80$, and $100 \mathrm{mM} \mathrm{K}^{+}$).

\section{Specific Morphologic Features of the NEB Microenvironment in Murine Lung Slices}

Our immunostainings for NEBs, Clara cells, and tight junctions have highlighted the complexity of the so-called NEB microenvironment in lung slices. NEB cells appeared to have a very limited luminal accessibility because their surface is largely shielded by Clara-like cells, sealed with tight junctions (see scheme in Figure 7G), while it is known that a network of multiple nerve fiber populations contacts NEBs and protrudes between the NEB cells from the basal side (2). It is not clear how electrophysiological patch clamp methods, which have been used to address the physiology of NEB cells in lung slices $(31,32)$, could be able to discriminate between recordings from NEB cells and from the Clara-like cells that cover NEBs in our model. Considering the fact that the thin apical processes of NEB cells that are in contact with the airway lumen bear long microvilli, while the Clara-like cells on top of NEBs have large flat surfaces (10), the chances of successfully performing voltage or current clamp recordings of surface membranes of the invisible thin processes of NEB cells seem to be very limited. The presented confocal multipoint analysis method is perfectly positioned to address this complexity of the NEB environment in lung slices, as it allows discriminating between recordings from NEBs and nearby other cell types in the airway epithelium, based on morphologic characteristics and the specific fluorescent patterns obtained with 4-Di-2-ASP staining and Fluo-4 loading (see schematic summary in Figure 7G).

\section{Validation and Mode of Action of the Fluorescent Styryl Dye 4-Di-2-ASP in Murine Lung Slices}

We have reported earlier that the styryl pyridinium dye 4-Di-2ASP is a reliable marker for the identification of pulmonary NEBs as fluorescent cell groups in ex vivo lung slices (24) and airway whole mounts (33) of several species, and the present study revealed that ciliated cells in the lung slices also take up 4-Di-2-ASP.

It was further shown that the responses of NEB cells and ciliated cells to the mitochondrial uncoupler FCCP were for 4-Di-2-ASP-loaded cells highly comparable with that of cells loaded with JC-1, an established $\Delta \psi_{\mathrm{m}}$ indicator. Considering that it has been suggested that styryl dyes are potentially useful probes for measuring changes in $\Delta \psi_{\mathrm{m}}(25-27)$, the latter is thought to confirm that 4-Di-2-ASP detects changes in $\Delta \psi_{\mathrm{m}}$. The reversibility of JC-1 fluorescence was slow and incomplete, as has been reported before $(34,35)$. The observation that the effects of FCCP on the 4-Di-2-ASP fluorescence were rapidly reversible suggests that 4-Di-2-ASP has little or no impact on the physiology of the 4-Di-2-ASP accumulating cell types.

The exact mechanism of selective 4-Di-2-ASP incorporation and function as a $\Delta \psi_{\mathrm{m}}$ indicator is currently unknown. Based on the observation that the cytoplasm of NEB cells and ciliated cells became more 4-Di-2-ASP fluorescent after $\Delta \psi_{\mathrm{m}}$ depolarization with FCCP, and on the lipophilic cationic features of this dye, a mechanism similar to that described for the $\Delta \psi_{\mathrm{m}}$ indicator Rhodamine 123 and its derivatives $(36,37)$ may be expected. 4-Di-2-ASP would then be accumulated in the mitochondrial matrix, attracted by the large negative potential established by the electron-transport chain, whereby its fluorescence is quenched. Manipulations that directly depolarize $\Delta \psi_{\mathrm{m}}$, such as uncouplers, most likely increase the fluorescence intensity of 4-Di-2-ASP by redistribution of the dye into the cytosol, with a consequent loss of quenching.

Since an indicator of $\Delta \psi_{\mathrm{m}}$ is not expected to give reliable information about the general activation of cells, we combined 4-Di-2-ASP staining with the fluorescent $\mathrm{Ca}^{2+}$ indicator Fluo-4, which has proven its use in other in situ preparations (38-40) and has fluorescence spectra compatible with the simultaneous visualization of 4-Di-2-ASP. 

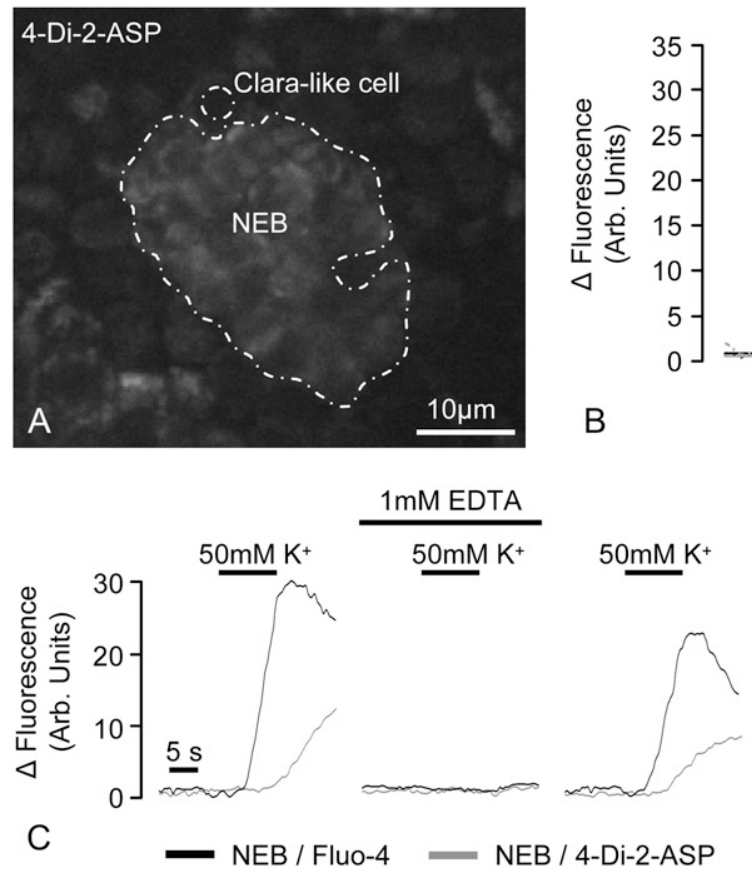

B
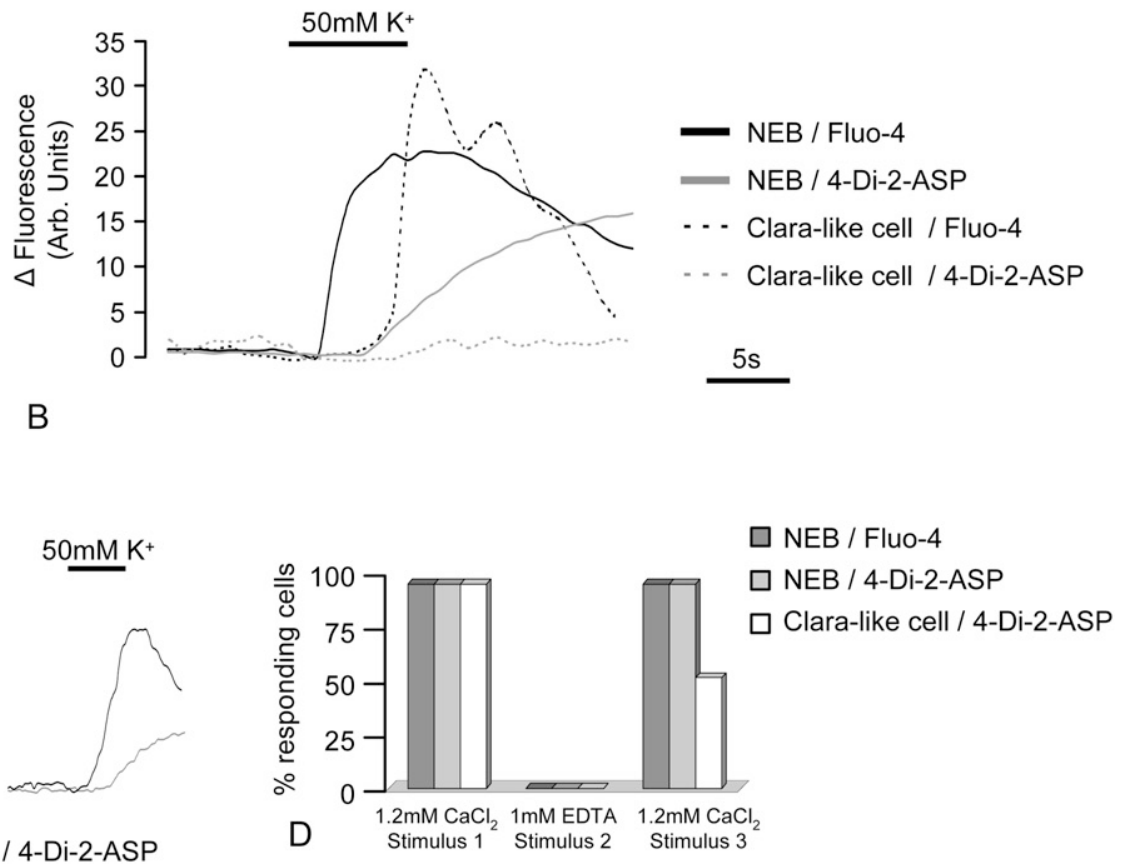

Figure 5. $(A, B)$ Representative recording of alternatively captured images of 4-Di-2-ASP and Fluo-4 fluorescence and intensity measurements in a NEB and Clara-like cell in a 4-Di-2-ASP-stained, Fluo-4-loaded ex vivo lung slice, before, during, and after a 10-second challenge with 50 mM $\left[\mathrm{K}^{+}\right]_{\mathrm{o}}$. (A) 4-Di-2-ASP staining recorded before the experiment, showing a NEB that is easily differentiated from the surrounding nonfluorescent Clara-like cells. (B) Graph plotting the time course of Fluo-4 and 4-Di-2-ASP fluorescence intensity as measured in the NEB and Clara-like cell depicted in the 4-Di-2-ASP image. The traces are superimposed to allow easier comparison of the temporal sequence of the two events. NEB cells respond to the pulse of high $\left[\mathrm{K}^{+}\right]_{\mathrm{o}}$ with a clear rise in Fluo-4 fluorescence, apparently a few seconds before the Clara-like cell shows a reaction. In addition, NEB cells respond to high $\left[\mathrm{K}^{+}\right]_{\mathrm{o}}$ with a rise in 4-Di-2-ASP fluorescence, while the Clara-like cell shows no reaction. Note that the high [ $\left.\mathrm{K}^{+}\right]_{\circ}$ induced increase in Fluo-4 fluorescence in NEB cells precedes the 4-Di-2-ASP response by a few seconds. Time-lapse images are shown in Video E6. $(C, D)$ Graphs showing changes in the alternately captured 4-Di-2-ASP and Fluo-4 fluorescence intensity in a 4-Di-2-ASP-stained, Fluo-4-loaded lung slice, illustrating the dependence on $\left[\mathrm{Ca}^{2+}\right]_{\mathrm{o}}$ of the Fluo-4 and 4-Di-2-ASP response to high $\left[\mathrm{K}^{+}\right]_{\mathrm{o}}$-induced depolarization. (C) Exemplar recording from a NEB. For the period indicated, the physiological superfusate was replaced by a buffer without $\mathrm{CaCl}_{2}$ and including 1 mM EDTA. During this period, application of $50 \mathrm{mM}\left[\mathrm{K}^{+}\right]_{\mathrm{o}}$ had no effect. Upon return to the control superfusate, the Fluo-4 and 4-Di-2-ASP responses were restored. (D) Bar graph showing the percentage of NEBs $(n=13)$ and Clara-like cells $(n=54)$ that showed a Fluo-4 and 4-Di-2-ASP response after stimulation with $50 \mathrm{mM}\left[\mathrm{K}^{+}\right]_{\mathrm{o}}$ in control conditions, without $\left[\mathrm{Ca}^{2+}\right]_{\mathrm{o}}$, and upon return to the control solution. Note that the responses to high $\left[\mathrm{K}^{+}\right]_{\mathrm{o}}$ were completely abolished in $\mathrm{Ca}^{2+}$-free solution, and that after returning to control external $\mathrm{Ca}^{2+}$, the responses in NEBs fully recovered, while only $54 \%$ of the Clara-like cells exhibited a renewed Fluo-4 response.

\section{Functional Imaging of Airway Epithelial Cells in Ex Vivo Lung Slices: Special Reference to Pulmonary NEBs}

Clara cells and ciliated cells. The present study revealed that, in addition to NEBs, ciliated cells in the lung slices also take up 4-Di-2-ASP. Since it has been reported that the epithelium of mouse intrapulmonary airways is mainly composed of ciliated cells $(\sim 30 \%)$ and nonciliated Clara cells $(\sim 65 \%)(41)$, it may be concluded that the majority of the airway epithelial cells that are nonciliated and do not stain with 4-Di-2-ASP are Clara cells.

We currently have no conclusive evidence that explains why Clara and Clara-like cells appear to take up less of the mitochondrial dyes compared with ciliated cells. Since 4-Di-2-ASP is a lipophylic membrane dye, differences in long-term staining between cell types might be due to differences in membrane recycling or other aspects of the so far poorly understood uptake mechanism. On the other hand, a dissimilar distribution, density, and accessibility of the mitochondria in both cell types cannot be excluded. In ciliated cells, mitochondria are abundant in the apical region of the cell among the ciliary rootlets (42). Clara cells, on the other hand, display a relatively low density of mitochondria that are distributed throughout the cell (43).

Similar to the 4-Di-2-ASP staining, loading with Fluo-4 also resulted in a typical basal labeling pattern in the lung slices, enabling the discrimination of bright ciliated cells and virtually non-fluorescent Clara cells. Although ciliated cells revealed a bright Fluo-4 fluorescence, their cell membranes appeared to be intact, as indicated by the lack of PI incorporation. Some airway smooth muscle cells, on the other hand, were observed to contain PI labeled nuclei, a phenomenon that was explained before as an inevitable consequence of making vibratome slices (24).

After application of $10 \mu \mathrm{M}$ ATP, Clara cells and ciliated cells showed an activation pattern similar to that described earlier in other in vivo (44) and in vitro (45) models, confirming the functionality of our lung slice model.

Neuroepithelial bodies. Combined live staining with 4-Di-2ASP and Fluo-4 appeared to be essential for performing selective $\mathrm{Ca}^{2+}$ imaging experiments of pulmonary NEBs.

To confirm Fluo-4 loading of NEB cells and to test their capacity to adequately react to applied stimuli, an appropriate and selective positive control was mandatory for the further development of our ex vivo lung slice model. NEBs are excitable cells that express voltage-gated $\mathrm{Ca}^{2+}$ channels $(46,47)$, which would be expected to open during depolarization evoked by high $\left[\mathrm{K}^{+}\right]_{\mathrm{o}}$. The present study for the first time demonstrated that depolarizing stimuli indeed resulted in a fast rise of the cytoplasmic free $\mathrm{Ca}^{2+}$ concentration in pulmonary NEBs, which started approximately 1.5 seconds after stimulation. It was confirmed that short-term elevation of $\left[\mathrm{K}^{+}\right]_{\mathrm{o}}$ causes a reversible 


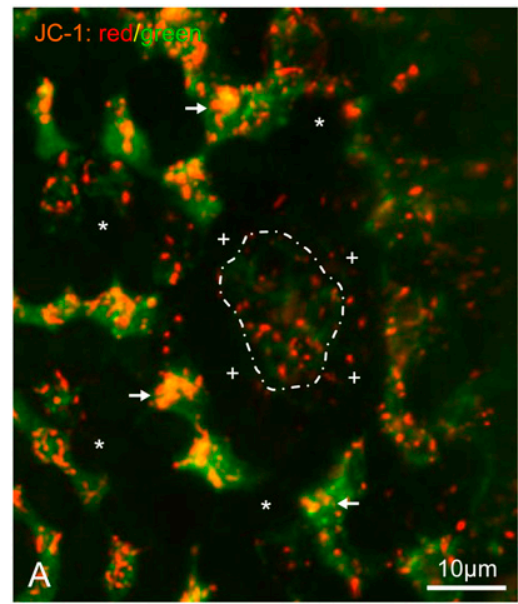

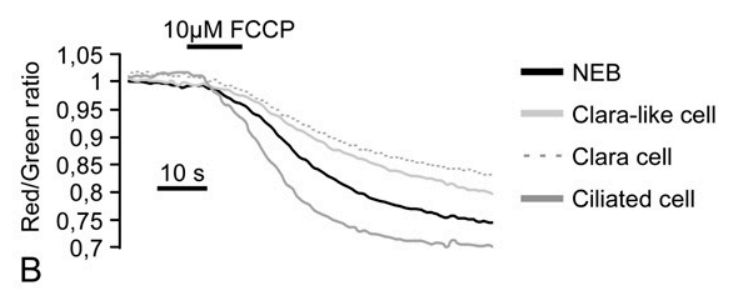

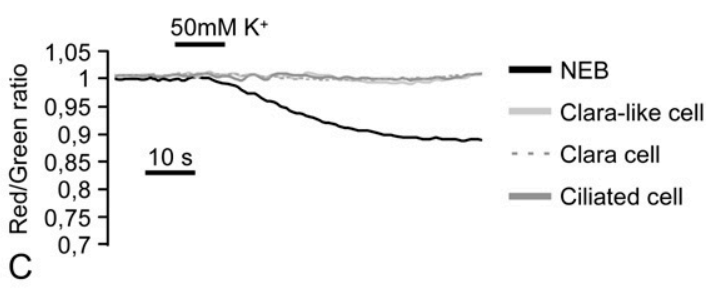

Figure 6. (A) Confocal image showing a luminal view of a mouse airway loaded with the mitochondrial membrane potential $\left(\Delta \psi_{\mathrm{m}}\right)$ indicator JC-1, allowing visible identification of a NEB (encircled), red fluorescent polygonal ciliated cells (arrows), and almost nonfluorescent Clara (asterisks) and Clara-like cells (crosses). (B) Representative recording of the changes in JC-1 red/green fluorescence ratio as measured in a NEB, Clara cell, ciliated cell, and Clara-like cell before, during, and after a 20-second challenge with $10 \mu \mathrm{M}$ FCCP. All epithelial cells respond to application of FCCP with a decrease in the ratio of JC- 1 red/green fluorescence, indicative of $\Delta \psi_{\mathrm{m}}$ depolarization. Notice that the trace does not return to basal values upon washing with physiological solution. (C) Graph plotting the time course of the JC-1 red/green fluorescence ratio as measured in a NEB, Clara cell, ciliated cell, and Clara-like cell before, during, and after a 30 -second challenge with high $\left[\mathrm{K}^{+}\right]_{\mathrm{o}}(50 \mathrm{mM})$. The JC-1 $\mathrm{red} / \mathrm{green}$ fluorescence ratio decreases in the NEB, but not in the other epithelial cell types. Time-lapse images are shown in Video E7.

and reproducible depolarization of NEB cells, causing influx of extracellular $\mathrm{Ca}^{2+}$, without signs of a negative effect on the physiological properties of the cells.

By recording changes in 4-Di-2-ASP or JC-1 fluorescence, we observed that stimulation with high $\left[\mathrm{K}^{+}\right]_{\mathrm{o}}$ additionally depolar- ized $\Delta \psi_{\mathrm{m}}$ in NEB cells. The 4-Di-2-ASP response to high $\left[\mathrm{K}^{+}\right]_{\mathrm{o}}$ started approximately 2 seconds later than seen after $\Delta \psi_{\mathrm{m}}$ depolarization with FCCP, indicative of an indirect mechanism. Moreover, the response was delayed by 4 seconds compared with the rise in Fluo-4 fluorescence, and both were dependent on the
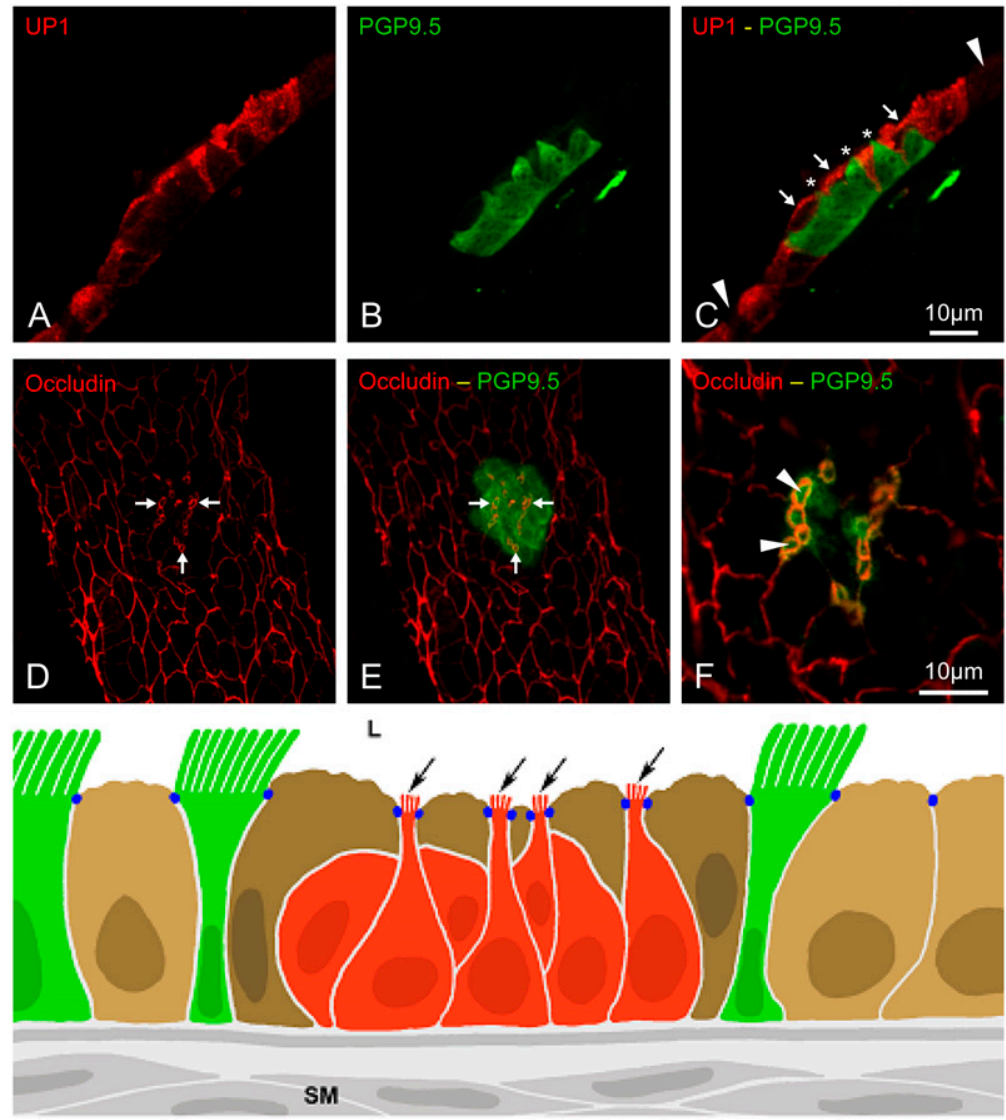

NEB cells (basal 4-Di-2-ASP high / basal Fluo-4 low / fast Fluo-4 rise after high K+)

Clara-like cells (basal 4-Di-2-ASP low / basal Fluo-4 low / delayed Fluo-4 rise after high $\mathrm{K}+$ )

Clara cells (basal 4-Di-2-ASP low / basal Fluo-4 low / no Fluo-4 rise after high $\mathrm{K}+$ )

Ciliated cells (basal 4-Di-2-ASP high / basal Fluo-4 high / no Fluo-4 rise after high $\mathrm{K}+$ )

- Tight junctions
Figure 7. (A-C) Immunocytochemical double labeling for Urine Protein 1 ( $A$; UP1; red Cy3 fluorescence), a marker of Clara cells, and protein gene-product 9.5 ( $B$; PGP9.5; green FITC fluorescence), a pan-neuronal and neuroendocrine marker, in a murine lung slice. (C) Combination of the red and green channel reveals that PGP9.5-immunoreactive NEB cells are almost entirely covered by UP1-immunoreactive Clara-like cells (arrows), shielding the NEB cells from the airway lumen. Some of the NEB cells, however, appear to reach the airway lumen via a thin apical process (asterisks). Somewhat further away from the NEB, UP1-negative cells, reminiscent of ciliated cells (arrowheads), are seen. $(D-F)$ Immunocytochemical double staining for occludin (red Cy3 fluorescence), a transmembrane protein of tight junction complexes, and PGP9.5 (green FITC fluorescence) in a mouse lung slice. $(D)$ Red channel showing that the rather regular honey comb pattern of the occludin-immunoreactive tight junctions is disturbed by tight junction complexes delineating much smaller areas that are arranged in rows (arrows). (E) Double labeling for PGP9.5 reveals that the spots with aberrant tight junction patterns (arrows), always coincide with the presence of an underlying NEB. Maximum value projection of 23 confocal optical sections. $(F)$ Single optical section at the luminal surface, showing that the small tight junction encircled areas correspond to the tip of individual NEB cells that contact the airway lumen (arrowheads; green PGP9.5 staining). (G) Schematic summary of the structural organization of a transverse section of the NEB environment as seen in ex vivo mouse lung slices. Both the basal fluorescence after double loading the slices with 4-Di-2-ASP and Fluo-4, and changes in Fluo-4 fluorescence seen after stimulation with high $\left[\mathrm{K}^{+}\right]_{\mathrm{O}}$, are indicated for different airway epithelial cell types. Also note the tight junctions that were seen to "suture" all apical cell-cell contacts, including the small areas of NEB cell processes that reach the airway lumen between Clara-like cells (arrows). SM, airway smooth muscle; $\mathrm{L}$, airway lumen. 
influx of extracellular $\mathrm{Ca}^{2+}$. These observations strongly argue for $\Delta \psi_{\mathrm{m}}$ depolarization via an indirect mechanism depending on the cytoplasmic $\mathrm{Ca}^{2+}$ rise. Similar observations have been made in several other excitable cells, including rat cerebellar granule neurons (48), rat cortical astrocytes (49), mouse dorsal root ganglion cells (50), and rabbit carotid body type I cells (51). The studies suggest a common pathway, whereby high $\left[\mathrm{K}^{+}\right]_{\mathrm{o}}$ depolarizes the cell membrane, evoking influx of extracellular $\mathrm{Ca}^{2+}$, activating uptake of $\mathrm{Ca}^{2+}$ via the mitochondrial calcium uniporter into mitochondria, which in turn depolarizes the mitochondria. We would like to propose that the latter signaling cascade may also be functional in pulmonary NEB cells.

Clara-like cells. Application of high $\left[\mathrm{K}^{+}\right]_{\mathrm{o}}$ typically also evoked a $\mathrm{Ca}^{2+}$ response in the rounded 4-Di-2-ASP-negative cells that encircle NEBs, but not in other epithelial cells. Although a selective marker for Clara-like cells is currently not available, we were able to identify these cells as Clara-like cells based on their ex vivo staining characteristics, morphology, and typical location, selectively covering the lateral and apical surfaces of NEBs (8-10). Moreover, the $\left[\mathrm{Ca}^{2+}\right]_{i}$ rise provides a useful additional feature to discriminate Clara-like cells from the abundant Clara cells. Remarkably, the response of Claralike cells to high $\left[\mathrm{K}^{+}\right]_{\mathrm{o}}$ was delayed by approximately 4 seconds compared with $\mathrm{NEB}$ cells, and onset of the $\left[\mathrm{Ca}^{2+}\right]_{\mathrm{i}}$ rise in individual Clara-like cells appeared to be variable, while all cells in an NEB responded simultaneously. These observations are suggestive of an indirect activation of Clara-like cells by high $\left[\mathrm{K}^{+}\right]_{\mathrm{o}}$, potentially via exocytosis of NEB transmitters or gap junctional communication. Evidently, the reported experiments are not sufficient to prove this hypothesis, but certainly open perspectives for a thorough investigation of the potential interactions between pulmonary NEB cells and Clara-like cells.

\section{CONCLUSIONS}

This study for the first time demonstrates the possibility to specifically visualize NEBs and their responses to applied stimuli in an ex vivo lung slice model, using a live cell imaging set-up based on fluorescent $\mathrm{Ca}^{2+}$ and $\Delta \psi_{\mathrm{m}}$ indicators. In addition to NEBs, the model allows the simultaneous visualization of physiological activity in other airway-related cell types, such as Claralike cells, Clara cells, and ciliated cells, which can all be specifically identified in the lung slices. Moreover, results obtained so far on the model suggest a possible functional interaction between NEB cells and the surrounding Clara-like cells in the NEB microenvironment. Our findings highlight that NEBs are part of a complex unit in the airway epithelium, which cannot be properly addressed by previously described models. The new model offers excellent possibilities to further unravel the functional significance of pulmonary NEBs in healthy and diseased lungs.

Conflict of Interest Statement: None of the authors has a financial relationship with a commercial entity that has an interest in the subject of this manuscript.

Acknowledgments: The authors especially thank J. Van Daele and D. De Rijck for help with microscopy, imaging, and illustrations; S. Goethals for support with data processing; and S. Kockelberg and H. De Pauw for administrative help.

\section{References}

1. Lauweryns JM, Peuskens JC. Neuro-epithelial bodies (neuroreceptor or secretory organs?) in human infant bronchial and bronchiolar epithelium. Anat Rec 1972;172:471-481.

2. Adriaensen D, Brouns I, Van Genechten J, Timmermans J-P. Functional morphology of pulmonary neuroepithelial bodies: extremely complex airway receptors. Anat Rec 2003;270A:25-40.

3. Sorokin SP, Hoyt RF. Neuroepithelial bodies and solitary small-granule cells. In: Massaro D, editor. Lung cell biology. New York: Marcel Dekker; 1989. pp. 191-344.
4. Adriaensen D, Timmermans J-P. Purinergic signalling in the lung: important in asthma and COPD? Curr Opin Pharmacol 2004;4:207214.

5. Adriaensen D, Scheuermann DW. Neuroendocrine cells and nerves of the lung. Anat Rec 1993;236:70-85.

6. Brouns I, Pintelon I, Van Genechten J, De Proost I, Timmermans J-P, Adriaensen D. Vesicular glutamate transporter 2 is expressed in different nerve fibre populations that selectively contact pulmonary neuroepithelial bodies. Histochem Cell Biol 2004;121:1-12.

7. Adriaensen D, Brouns I, Pintelon I, De Proost I, Timmermans J-P. Evidence for a role of neuroepithelial bodies as complex airway sensors: comparison with smooth muscle-associated airway receptors. J Appl Physiol 2006;101:960-970.

8. Hung K-S. Development of neuroepithelial bodies in pre- and postnatal mouse lungs: scanning electron microscopic study. Anat Rec 1982;203: 285-291.

9. Pearsall AD, Hoyt RF, Sorokin SP. Three-dimensional reconstruction of a small-granule paracrine cell cluster in an adult hamster bronchus. Anat Rec 1985;212:132-142.

10. Haller CJ. A scanning and transmission electron microscopic study of the development of the surface structure of neuroepithelial bodies in the mouse lung. Micron 1994;25:527-538.

11. Reynolds SD, Giangreco A, Power JH, Stripp BR. Neuroepithelial bodies of pulmonary airways serve as a reservoir of progenitor cells capable of epithelial regeneration. Am J Pathol 2000;156:269-278.

12. Bishop AE. Pulmonary epithelial stem cells. Cell Prolif 2004;37:89-96.

13. Hong KU, Reynolds SD, Giangreco A, Hurley CM, Stripp BR. Clara cell secretory protein-expressing cells of the airway neuroepithelial body microenvironment include a label-retaining subset and are critical for epithelial renewal after progenitor cell depletion. Am J Respir Cell Mol Biol 2001;24:671-681.

14. Reynolds SD, Hong KU, Giangreco A, Mango GW, Guron C, Morimoto Y, Stripp BR. Conditional clara cell ablation reveals a selfrenewing progenitor function of pulmonary neuroendocrine cells. Am J Physiol Lung Cell Mol Physiol 2000;278:L1256-L1263.

15. Carabba VH, Sorokin SP, Hoyt RFJ. Development of neuroepithelial bodies in intact and cultured lungs of fetal rats. Am J Anat 1985;173: $1-27$.

16. Cutz E, Yeger H, Wong V, Bienkowski E, Chan W. In vitro characteristics of pulmonary neuroendocrine cells isolated from rabbit fetal lung: I. Effects of culture media and nerve growth factor. Lab Invest 1985;53:672-683.

17. Speirs V, Cutz E. An overview of culture and isolation methods suitable for in vitro studies on pulmonary neuroendocrine cells. Anat Rec 1993;236:35-40.

18. Speirs V, Wang YV, Yeger H, Cutz E. Isolation and culture of neuroendocrine cells from fetal rabbit lung using immunomagnetic techniques. Am J Respir Cell Mol Biol 1992;6:63-67.

19. Kemp PJ, Lewis A, Hartness M, Searle GJ, Miller P, O'Kelly I, Peers C. Airway chemotransduction: from oxygen sensor to cellular effector. Am J Respir Crit Care Med 2002;166:S17-S24.

20. O'Kelly I, Stephens RH, Peers C, Kemp PJ. Potential identification of the $\mathrm{O}_{2}$-sensitive $\mathrm{K}^{+}$current in a human neuroepithelial body-derived cell line. Am J Physiol 1999;276:L96-L104.

21. Lauweryns JM, Van Lommel A. Effect of various vagotomy procedures on the reaction to hypoxia of rabbit neuroepithelial bodies: modulation by intrapulmonary axon reflexes. Exp Lung Res 1986;11:319-339.

22. Fu XW, Nurse CA, Wang YT, Cutz E. Selective modulation of membrane currents by hypoxia in intact airway chemoreceptors from neonatal rabbit. J Physiol 1999;514:139-150.

23. Fu XW, Nurse CA, Wong V, Cutz E. Hypoxia-induced secretion of serotonin from intact pulmonary neuroepithelial bodies in neonatal rabbit. J Physiol 2002;539:503-510.

24. Pintelon I, De Proost I, Brouns I, Van Herck H, Van Genechten J, Van Meir F, Timmermans J-P, Adriaensen D. Selective visualisation of neuroepithelial bodies in vibratome slices of living lung by 4-Di-2ASP in various animal species. Cell Tissue Res 2005;321:21-33.

25. Loew LM, Cohen LB, Salzberg BM, Obaid AL, Bezanilla F. Chargeshift probes of membrane potential. Characterization of aminostyrylpyridinium dyes on the squid giant axon. Biophys $J$ 1985;47:71-77.

26. Rafael J, Nicholls DG. Mitochondrial membrane potential monitored in situ within isolated guinea pig brown adipocytes by a styryl pyridinium fluorescent indicator. FEBS Lett 1984;170:181-185.

27. Mewes H-W, Rafael J. The 2-(dimethylaminostyryl)-1-methylpyridinium cation as indicator of the mitochondrial membrane potential. FEBS Lett 1981;131:7-10. 
28. Bernard A, Roels H, Lauwerys R, Witters R, Gielens C, Soumillion A, Van Damme J, De Ley M. Human urinary protein 1: evidence for identity with the Clara cell protein and occurence in respiratory tract and urogenital secretions. Clin Chim Acta 1992;207:239-249.

29. Brouns I, Van Nassauw L, Van Genechten J, Majewski M, Scheuermann DW, Timmermans J-P, Adriaensen D. Triple immunofluorescence staining method with antibodies raised in the same species to study the complex innervation pattern of intrapulmonary chemoreceptors. J Histochem Cytochem 2002;50:575-582.

30. Negoescu A, Labat-Moleur F, Lorimier P, Lamarq L, Guillermet C, Chambaz E, Brambilla EF. (ab) secondary antibodies: a general method for double immunolabeling with primary antisera from the same species. Efficiency control by chemiluminescence. J Histochem Cytochem 1994:42:433-437.

31. Fu XW, Wang D, Nurse CA, Dinauer MC, Cutz E. NADPH oxidase is an $\mathrm{O}_{2}$ sensor in airway chemoreceptors: evidence from $\mathrm{K}^{+}$current modulation in wild-type and oxidase-deficient mice. Proc Natl Acad Sci USA 2000;97:4374-4379.

32. Fu XW, Nurse CA, Farragher SM, Cutz E. Expression of functional nicotinic acetylcholine receptors in neuroepithelial bodies of neonatal hamster lung. Am J Physiol Lung Cell Mol Physiol 2003;285:12031212.

33. De Proost I, Pintelon I, Brouns I, Timmermans J-P, Adriaensen D. Selective visualisation of sensory receptors in the smooth muscle layer of ex vivo airway whole mounts by styryl pyridinium dyes. Cell Tissue Res 2007;329:421-431.

34. Feldkamp T, Kribben A, Weinberg JM. Assessment of mitochondrial membrane potential in proximal tubules after hypoxia-reoxygenation. Am J Physiol Renal Physiol 2004;288:F1092-F1102.

35. Feeney CJ, Pennefather PS, Gyulkhandanyan AV. A cuvette-based fluorometric analysis of mitochondrial membrane potential measured in cultured astrocyte monolayers. J Neurosci Methods 2003;125:1325 .

36. Scaduto RC, Grotyohann LW. Measurement of mitochondrial membrane potential using fluorescent rhodamine derivatives. Biophys $J$ 1999;76:469-477.

37. Emaus RK, Grunwald R, Lemasters JJ. Rhodamine 123 as a probe of transmembrane potential in isolated rat-liver mitochondria: spectral and metabolic properties. Biochim Biophys Acta 1986;850:436448.

38. Oishi H, Budel S, Schuster A, Stergiopulos N, Meister J-J, Bény J-L. Cytosolic-free calcium in smooth-muscle and endothelial cells in an intact arterial wall from rat mesenteric artery in vitro. Cell Calcium 2001;30:261-267.

39. Peti-Peterdi J. Calcium wave of tubuloglomerular feedback. Am J Physiol Renal Physiol 2006;291:F473-F480.

40. Burdyga T, Shmygol A, Eisner DA, Wray S. A new technique for simultaneous and in situ measurements of $\mathrm{Ca}^{2+}$ signals in arteriolar smooth muscle and endothelial cells. Cell Calcium 2003;34:27-33.

41. Pack RJ, Al-Ugaily L, Morris GF. The cells of the tracheobronchial epithelium of the mouse: a quantitative light and electron microscopy study. J Anat 1981;132:71-84.

42. Lee RKMW, Forrest JB. Structure and function of cilia. In: Crystal RG, West JB, Weibel ER, Barnes PJ, editors. The lung: scientific foundations, 2nd ed. Philadelphia: Lippincott-Raven Publishers; 1997. pp. $459-478$.

43. Plopper CG, Hyde DM, Buckpitt AR. Clara cells. In: Crystal RG, West JB, Weibel ER, Barnes PJ, editors. The lung: scientific foundations, 2nd ed. Philadelphia: Lippincott-Raven Publishers; 1997. pp. 517533.

44. Knowles MR, Clarke LL, Boucher RC. Activation by extracellular nucleotides of chloride secretion in the airway epithelia of patients with cystic fibrosis. $N$ Engl J Med 1991;325:533-538.

45. Van Scott MR, Chinet TC, Burnette AD, Paradiso AM. Purinergic regulation of ion transport across nonciliated bronchiolar epithelial (Clara) cells. Am J Physiol 1995;269:L30-L37.

46. Youngson C, Nurse C, Wang D, Cutz E. Ionic currents and oxygensensing mechanism in neuroepithelial body cells. In: Cutz E, editor. Cellular and molecular biology of airway receptors Heidelberg, Germany: Springer-Verlag; 1997. pp. 71-108.

47. De Proost I, Brouns I, Pintelon I, Timmermans J-P, Adriaensen D. Pulmonary expression of voltage-gated calcium channels: special reference to sensory airway receptors. Histochem Cell Biol 2007;128: 301-316.

48. Xiong J, Camello PJ, Verkhratsky A, Toescu EC. Mitochondrial polarisation status and $\left[\mathrm{Ca}^{2+}\right]_{\mathrm{i}}$ signalling in rat cerebellar granule neurones aged in vitro. Neurobiol Aging 2004;25:349-359.

49. Duchen MR. Mitochondria and calcium: from cell signalling to cell death. $J$ Physiol 2000;529:57-68.

50. Duchen MR. $\mathrm{Ca}^{2+}$-dependent changes in the mitochondrial energetics in single dissociated mouse sensory neurons. Biochem J 1992;283: $41-50$.

51. Biscoe TJ. Monitoring PO2 by the carotid body chemoreceptor. News Physiol Sci 1990;5:229-233. 